\title{
Mehmet Gönenli ve Türk Hukukuna Katkıları
}

\author{
Şamil DAĞCI \\ Doç. Dr., Ankara Üniversitesi İlahiyat Fakültesi \\ e-mail:samildagc1@hotmail.com
}

Abstract: “Gönenli's Life and His Contribution To Turkish Law" Mehmet Gönenli (1882-1956), who experienced both the last period of Ottoman State and the early period of newly emerged Turkish Republic, is a leading jurist of his time. Having graduated from the Faculty of Law (Maktab al-Qudat) he worked in the Office of Supreme Religious Board (Shayhu'l-Islamlik) as a consultant jurist. He also took part in preparation and issuance of official legal views in religious matters (al-fatawa). After the proclamation of Republic of Turkey he served as a member; later he became vice chairman of the Supreme Court of Appeal (Mahkama al-Tanyiz). In this article Gönenli's life and his contribution to Turkish Law has been treated in brief; together with a sample Draft Family Law Codification prepared by Gönenli's contemporary jurists.

Key Words: Faculty of Law, Office of Supreme Religious Board, Supreme Court of Appeal, Draft Family Law Codification.

\section{Giriş}

Eğitim ve öğretimini Osmanlı'nın son dönemlerinde tamamlamış, uzun süre o kültür atmosferi içinde yaşamış hatta, Devlet-i Aliyye'de önemli görevler üstlenmiş ancak, hayatının önemli bir kısmını da Cumhuriyet'in 
ilanından sonra bu yeni devletin hizmetine vermiş insanların, Osmanlı'dan Cumhuriyete geçiş dönemi kültür tarihimiz açısından büyük önemi bulunmaktadır. Çünkü bu mümtaz insanlar, günümüz neslini yakın tarihimize bağlayan âdeta birer köprü konumundadırlar. Bugün Tefsir, Fıkıh ve Kelam gibi temel İslam bilimlerinde Elmalılı Muhammet Hamdi, Karinâbâdlı Ömer Hilmi, Ömer Nasuhi Bilmen, Ali Himmet Berki, Ebu'lUlâ Mardin, İsmail Hakkı İzmirli ve Şerafeddin Yaltkaya gibi isimler henüz aşılamamışsa bu bilginler, günümüz ilim adamları için de yukarıda ifade ettiğimiz "bizi yakın tarihimize bağlayan birer köprü" olma fonksiyonlarını icra etmeye devam ediyorlar demektir. Makalenin konusunu teşkil eden Mehmet Gönenli de bu geçiş süreci içinde yer alan önemli hukuk bilginlerimizden birisidir.

\section{Eğitim ve Öğretim Hayatı}

Yaşadığı dönemde İslâm Hukuku'nun saygın bilginlerinden birisi olarak milletimizin hukukî ve adlî hayatına (15 yılı Osmanlı Devletinde, 35 yılı ise Cumhuriyet döneminde olmak üzere) yaklaşık 50 yıl hizmet veren Mehmet Gönenli, 1298 malî, 1299 hicrî ve 1882 milâdî yılında BalıkesirGönen ilçesi Babayaka Köyü'nde dünyaya gelmiştir. Babası Ahmet Efendi, annesi ise Hacer hanımdır. İlk ve Orta tahsilini (ibtidâiye ve rüstiye), Gönen'de yapmıştır. 15 Temmuz 1314/1898 tarihinde yılında Gönen Rüştiyesi'nden pekiyi (aliyyü'l-a'lâ) derece ile mezun olan Mehmet Gönenli, bundan sonraki tahsiline İstanbul'da devam etmiştir.' Gönen'den İstanbul'a gelen Mehmet Efendi, o dönemin meşhur âlimlerinden Fatih Camii ders-i âm'ı ve Mekteb-i Kudât (Hukuk Fakültesi) öğretim üyesi Tokatlı merhum Şakir Efendi'nin ${ }^{2}$ derslerine devam etmiş ve 1327 hicrî senesinde kendisinden icazet almıştır. ${ }^{3}$ Bilahare $1326 / 1910$ yılında "ders vekâleti"nce yapılan yeterlik (ruûs) imtihanlarını da başarı ile vermiş ve kendisi de ders-i âm olarak Fatih Camii'nde tedris hayatına başlamış; bu arada, devam etmekte olduğu Mekteb-i Kudât (Hukuk Fakültesi) tan da 25 Temmuz 1327/1911 yılında pekiyi derece ile mezun olarak tahsil hayatını ikmal etmiştir. ${ }^{4}$ İmiyye Sâlnâmesi'ndeki kayitlardan, Gönenli'nin meşhur hukukçu Ali Himmet Berki ile aynı fakülteden aynı yıl mezun oldukları anlaşılmaktadır.5 Mezuniyet sonrasında da kendisi ile uzun yıllar Yargıtay'da birlikte mesai arkadaşh

\footnotetext{
' Adliye Vekaleti, "Umûr-i Zatiye Müdüriyeti”ndeki 3393 numaralı sicil dosyası (s.2) ndan, Gönenli'nin hafız olduğu da anlaşılmaktadır.

2 Tokatlı Şakir Efendi için bkz. Sadık Albayrak, Son Devir Osınanlı Ulemâsı, Zafer Matbaası, İstanbul 1981, IV/105.

${ }^{3}$ Mehmet Gönenli’nin Adalet Bakanlı̆̆ı'ndaki 3393 numaralı şahsî sicil dosyası, s. 1.

- Ilmiyye Sâlnâmesi (Meşihat-ı Celîle-i Islâmiyye'nin Cerîde-i Resmiyyesine Mülhak), Matbaa-ı Âmire, İstanbul 1334, s.726. Ayrıca, Mehmet Gönenli'nin Adalet Bakanlığı'ndaki sicil dosyası, s.1.

s Ilmiyye Sâlnâmesi, s.726.
} 
hususu: "akdar-ı ilahiyye bizi tahsilde olduğu gibi Fetvâhâne-i Âliyye ve Şer'iyye Vekâleti Müşâvere Hey'eti Azalı̆̆ı'nda ve Temyiz Mahkemesi'nde bir arada bulunmak bahtiyarlığına mazhar kılmıştı" şeklinde takdir dolu bir uslûp kullanarak ifade etmiştir. ${ }^{6}$

\section{Kişiliği ve Resmî Görevleri}

Vazifesine son derece bağlı ve çok çalışkan bir zât olan Mehmet Gönenli'nin uzun süren memuriyet hayatında yıllık izin kullanmadığı, bütün memuriyet hayatı boyunca sadece mazereti sebebiyle altı defa izin kullandığı ifade edilmektedir. Sadakat örneği büyüklerimizin bu örnek davranışlarından günümüz gençliğinin, alacağı çok anlamlı mesajlar olmalıdır. Görevindeki üstün liyakati, sadakatı ve başarılı hizmetleri sebebiyle Gönenli, müteaddit defalar takdimameler ile taltif edilmiştir. ${ }^{8}$

Özel hayatında ve beşerî ilişkilerinde bir Osmanlı beyefendisi olan Mehmet Gönenli'nin halim-selim, hoş sohbet ve nüktedân bir kişiliğe sahip olduğu ifade edilmektedir." Meslek hayatında ise dikkat ve hakkaniyet ilkelerine riayet etme, Gönenli'nin en önemli vasıflarındandır. Yüksek bir hâkim olarak düşünce ve kanaatlerinde metin olan merhumun herhangi bir ilmî meseleyi en ince ayrıntısına kadar tetkik edip incelemedikçe re'y ve mütâlaada bulunmadığı, görü̧̧ beyan etmediği de belirtilmelidir. Bu bakımdan merhum Gönenlinin ideal bir hâkimde aranan nitelikleri sıralayan ve Mecelle'nin 1792. md.sinde ifadesini bulan "Hâkim hakîm, fehîm, müstakîm ve emîn, mekîn ve metîn olma" şartlarını taşıdığı anlaşılmaktadır. Merhumun ögrencilik ve mesai arkadaşlarından, dönemin Yargıtay II. Başkanı merhum Ali Himmet Berki'nin, Gönenli ile ilgili olarak " Gönenli Mehmet Efendi merhum da fitratın az yetiştirdiği zeka ve hüsn-i ahlâk sahibi zevattan idi. Hayatının ilk yıllarından sonuna kadar taşıdığı fazilet ve meziyetleri muhafaza etmiş, dünyanın hasis menfaatlerine kıymet vermemiştir." şeklindeki ifadeleri ${ }^{10}$ de O'nun kişiliği hakkında önemli ipuçları vermektedir.

Gönenli, yaşadığı dönemin sayılı İslâm Hukuku otoritelerinden birisi olarak kabul edilmektedir. İslâm ve Osmanlı hukuk kültürüne hakkıyla vâkıf olan Gönenli, kendisi gibi Osmanlı bakiyyesi olan Ali Himmet Berki, Ebu'lUla Mardin ve diğer arkadaşları ile birlikte adliye mahkemelerinin en üst merciini oluşturan Yargıtay'da ve Hukuk Fakültesi'nde önemli görevler ifa ederek, çağdaş hukukta da mütchassıs olduklarını ispat etmiş ve mazi ile istikbal arasında önemli bir fonksiyon icra etmişlerdir.

\footnotetext{
" Ali Himmet Berki, "Memleketimiz Kıymetli Evlâdından Birini Daha Kaybetti”, Diyanet Işleri Başkanlığ Dergisi, c.IV, sayı, 7-8, s.120.

7 Cemalettin Köscoğlu, "Büyük Bir Hukuk Bilgininin Ölümü” Adalet Dergisi, Yıl:56. Sayı 7 -

8, (Temmuz-Ağustos 1965), s.795-796.

${ }^{8}$ Adalet Bakanlığındaki Şahsî Sicil Dosyası, s.16.

${ }^{9}$ Köseoğlu, agm., s.796.

${ }^{10}$ Berki, agm, s. 120.
} 
Adalet Bakanlığı'ndaki tercüme-i hâl dosyasındaki kayıtlardan, Mehmet Gönenli'nin Arap ve Fars dillerine, okuyup yazacak (tekellüm ve kitabet) derecede, yani ileri düzeyde vâkıf olduğu anlaşılmaktadır."

Gönenli Mehmet Efendi, çeşitli devlet memurluklarında bulunmuştur. O, 1337 yllında Temyiz Mahkemesi (Yargıtay) Şer'iyye Dairesi'nde vakfiye araştırma ve inceleme uzmanı (Şer'iyye Dairesi Vakfiye Taharrî Mümeyyizi) olarak İstanbul ruûsu ünvanı ile devlet memurluğuna başlamışsır. ${ }^{12}$ Ayrıca Meşihat (Şeyhülislâmlık Makamı)'ın en önemli birimini, âdeta beynini oluşturan Fetvâhâne-i Âli'de, yani temel fikhî kaynaklardan faydalanarak fetva müsveddelerini hazırlayan dairede stajyer memur (mülazim müsevvid) olarak çalışmıştır. Yine yargıçlar tarafından verilen i'lâmları, tetkik ile görevli olan İlâmât Dairesi'nde uzmanlık (mümeyyizlik), Taharn̂-i mesail memurluğu ve İstanbul Müftülüğü'nde, fetva hazırlama uzmanı (müsevvid) olarak çeşitli hizmetlerde bulunmuştur. 10 Zilkade 1332/30 Eylül 1914 tarihli nizamname mucebince kurulan Dâru'l- Hilâfe Medresesi'nde, fikıh ilmi dersinin okutulması da, dersi de uhdesine verilen ${ }^{13}$ Mehmet Gönenli 1338/1922 yılında, Fetva Emini Muavinliği'ne atanmış ayrıca, Şer'iyye Vekâleti İfta Heyeti Üyeliği'ne tayin edilmiştir. ${ }^{14}$

Mehmet Gönenli'nin Cumhuriyet döneminde de önemli makamlarda görev yaptığı ve adlî hizmetlerde bulunduğu dikkatimizi çekmektedir. Bilindiği gibi Türkiye Cumhuriyeti Devleti'nin kurulması aşamasındaki sıkıntılı günlerde çalışmalarını, 3 yıl 4 ay Sivas'ta sürdüren Temyiz Mahkemesi (Yargıtay), Cunhuriyetin ilânından 15 gün sonra çıkarılan 14.11.1923 gün ve 371 sayılı yasa ile ilga edilmiş ve Eskiş̧ehir'de "Mahkeme-i Temyiz" adıyla yeniden kurulmuştur. Gönenli Mehmet Efendi, Seyyid Bey'in (1289/1873-1925) Adalet Bakanlığı sırasında Eskişehir'de tesis edilen bu Temyiz. Mahkemesi'nde önce Şer'iyye Dairesi üyeliğine, bilahare İkinci Hukuk Dairesi üyeliğine atanmış, daha sonra, bu dairenin II. Hukuk dairesine tahvil edilmesi üzerine de, II. Hukuk Dairesi üyeliğine atanmış ve yüksek hâkim olarak görev yapmıştır. ${ }^{15}$

Mehmet Gönenli, Cumhuriyetin ilk yıllarındaki kanunlaştırma (codification) faaliyetlerine de katılmış, kanun hazırlama komisyonlarında üye sıfatıyla yer almıştır.

Cumhuriyetin henüz ilân edilmesinden önce Adliye Vekaleti (Adalet

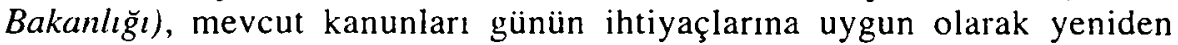
düzenlemek yani tadil etmek üzere birkaç komisyon teşkil etmiştir. "Vâcibât" ve "Ahkâm-ı Şahsiyye"den oluşan "Medeni Kanun Komisyonu"

\footnotetext{
"Adalet Bakanlığındaki Şahsî Sicil Dosyası, s.2.

${ }^{12}$ Recai Seçkin, Yargıtay Tarihçesi Kuruluş ve Işleyişi, Ankara 1967, s.403.

${ }^{13}$ Sicil Dosyasındaki bilgiler, 10 Zilkade 1332 tarihli nizamname ile kurulan Dâru'l-Hilâfe Medresesi'nde okutulan Fikıh dersinin. Gönenli'nin uhdesine verildiğini göstermektedir.

is Bkz. Şahsî Sicil Dosyası, s.3; ayrıca bkz. Cemalcttin Köseoğlu, "Büyük Bir Hukuk Bilgininin Ölümü" Adalet Dergisi, Yıl:56, Sayı 7-8, (Temmuz-Ağustos 1965), s.795-796.

${ }^{15}$ Şahsî Sicil Dosyası, s.3.
} 
da bunlar arasındadır. Vâcibât Komisyonu, Borçlar Hukuku ile ilgili hükümleri tadil ederek hazırlayacak; Ahkâm-ı Şahsiyye Komisyonu ise Şer'î hükümleri ve toplumsal menfaatleri ön planda tutarak özel hukuka, aile hukukuna ilişkin hükümleri düzenleyecekti. Ahkâm-1 Şahsiyye Komisyonu'nu teşkil eden üyeler arasında Ömer Nasuhi Bilmen ile, Gönenli Mehmet Efendi'nin isimlerini de görmekteyiz. ${ }^{16}$ Yüksek bir hukukî ihtisas gerektiren böyle bir komisyonda yer almı̧ olması da Gönenli'nin, dönemin seçkin âlimleri arasında yer aldığını göstermektedir.

Ahkâm-1 Şahsiyye Komisyonu, hazırladığı kanun taslağını, toplantı zabitları ile birlikte maddeler halinde Ceride-i Adliyye'nin 1340 tarih ve 25 , 26, 27 ve 28. sayılarında neşretmiş̧ir. ${ }^{17}$ Ancak 36 oturumdan oluşan bu zabıtlar tetkik edildiğinde Gönenli Mehmet Efendi'nin hastalığı sebebiyle oturumlara katılamadığı da maalesef müşahede edilmektedir. ${ }^{18}$ Gönenlinin aktif katılımda bulunmamasına rağmen, sadece dönemin kodifikasyon tekniğini ve Hukuk tarihimiz sürecinde İslâm Aile Hukuku'nun geçirdiği istihaleleri takip açısından önemli bir vesika olması ve bu konuya dair bir fikir verebileceği mülahazasıyla bu kanun taslağının maddelerini sadeleştirerek makalemizin sonuna ilave ettik. Bu kanun taslağı ayrı bir makalemizde tahlil edilecektir.

\section{Eserleri :}

a. Türk Hukuk Lügati'ndeki Maddeleri

Türk Hukuk Kurumu, sahasında uzman olan 30'dan fazla ilim adamı Profesör ve hukukçuya ansiklopedik bir hukuk sözlüğü hazırlatmıştır. Bugün bile elimizde en önemli Türkçe hukuk sözlüğü olma niteliğini koruyan bu eserde hukukî kavramların Latince, Fransızca, İngilizce ve Almanca karşılıkları da yer almaktadır. Milli Eğitim Bakanlığı tarafından 1944 yılında Türk Hukuk Lügati ismiyle bastırılan 582 sayfalık bu sözlüğün İslâm Hukuku ile ilgili maddeleri, İstanbul Üniversitesi Hukuk Fakültesi Öğretim Üyesi Ord. Prof. Dr. Ebu'l-Ula Mardin başkanlığında teşkil edilen bir heyet tarafından hazırlanmıştır. Bu ilmî heyette dönemin mütehassıs İ̀sâm

16 Ahkâm-ı Şahsiyye Komisyonu, Mülga Şûray-ı Devlet (Danışay) Tanzimat Daircsi Reisi Sadeddin Beyefendi'nin başkanlığında, Hukuk Fakültesi'nden dört öğretim üyesi (Muammer Bey. Hafız Şevket Efendi, Mişon Ventura ve Ahmet Samim Bey), ayrıca sâbık Şûray-ı Devlet azasından Kemal Atıf Bey ve Gönenli Mehmet Ffendi ile Erzurumlu Ömer Nasuhi Efendi'den oluşmaktadır. Bkz. Cerîde-i Adliyye, sene 1, Sayı 10. Mayıs1339, s.464.

17 Cerîde-i Adliyye. Ağustos 1340, sene: 2, Sayı 25, s.888-891; Sayı 26, s.953-957; Sayı 27. s.1033-1036.

18 Ahkâm-ı Şahsiyye Komisyonu Zabutları, s.3-15. Ceride-i Adliyye 12. sayıya ilave forma. Ömer Nasuhi Bilmen’in de hastalığını mazeret göstererek, komisyondan çekildiği anlaşılmaktadır. Cerîde-i Adliyye. Sayı 33, s.953. 
hukukçuları olarak Ali Himmet Berki ve Ömer Nasuhi Bilmen ile birlikte Yargıtay üyesi Mehmet Gönenli'nin adı da ${ }^{19}$ müşahede edilmektedir.

b. Ferâiz (Sade ve Açıklamalı) 132+10 sayfa, ${ }^{20}$

c. "Mesele-i Minberiyye" ve Mesele-i Şüreyhiyye"21.

Emekli olduktan sonra avukat ünvanıyla kaleme aldığı bu yazısında Gönenli, İslam miras hukuku'nun avliyye konusunu ele almıştır. Hz. Ali minberde hutbe irad etmekte iken dinleyicilerden birisi'nin kendisine yönelttiği miras hukukuna dair sorusunu minberde cevaplandırdığı için bu konu klasik $\mathrm{f}_{1} \mathrm{k}_{2}$ h kitaplarının ilgili bölümünde "mesele-i minberiyye” ismi ile yer almıştır. ${ }^{22}$

19 Türk Hukuk Lügatı'na Türk Hukuk Kurumu Başkanı ve Manisa Milletvekili Refik İnce tarafından yazılan önsöz, s.IX, XI.

n Gönen'deki Sempozyum'dan birkaç gün sonra bilvesile tebliğimizden haberi olduğunu söyleyen Fakültemiz üçüncü sınıf öğrencilerinden Ayşe Çalıkoğlu, kendisinin Gönen'li olduğunu, Mehmet Gönenli'nin de büyükbabası (babasının dedesi) olduğunu ifade etmiştir. Metrukatı arasında dedesinin yazdığı herhangi bir eser olup olmadığını araştırmasını isteğimiz üzerine Çalıkoğlu, mcrhumun kütüphanesinin, vefatından sonra dağıldığını, ancak kalan birkaç kitap arasında dedesinin isim ve imzasını taşıyan Miras Hukuku (feraiz) ile ilgili bir eseri bulunduğunu ifade etmiştir. "Feraiz (Sade ve Açıklamalı)" başığını taşıyan ve $132+10$ daktilo sayfasından oluşan escrinin başında mcrhum, bu kitabını yazıs amacının ".....kendine mahsus incelikleri olan bu ilim ile ilgili problemleri en kısa yoldan ve kesirsiz olarak çözebilmek için birtakım kurallar olduğunu, bu incelikleri bilenlerin herhangi bir sıkıntı çekmeksizin bunlart fözdüklerini, kendi amacının da Feraiz'in en önemli konularını kolay ve anlaşılabilir bir uslûp ile açıklamak..." olduğunu belirtmektedir. Eser'in sonunda 31 Aralık 1947 tarihi yer almaktadır. Bu değerli eseri, torunu Ayşe Çalıkoğlu neşrederek ilim dünyasına kazandırma çabasındadır.

21 Ankara Barosu Dergisi, y1l, 1954, say1, 2, ss. 134-137.

22 Bir dinleyici, minberde bulunduğu bir sırada Hz. Ali'ye, vefat eden ve mirasçı olarak; karısı, annesi ve iki kızı ile, babası bulunan bir kişinin mirasının nasıl taksim edileceğini, yani mirasçıların terekedeki paylarını sormuştur. İslâm miras hukuku (Ferâiz) hükümlerine göre mirasçılardan karı, mirasın 1/8'ini; ana 1/6'sını; kızlar 2/3'ünü; baba ise $1 / 6$ + taksimden artanı alacaktır. Gerekli matematikscl işlemler yapılıp paydalar eşitlendiğinde mirasçıların mirastan alacakları hisscler: $1 / 8$ (3) + $1 / 6(4)+2 / 3(8)+1 / 6(4)=3 / 24+4 / 24+16 / 24+4 / 24=27 / 24$ olmaktadir. Görüldüğ̆̈ gibi işlemde pay paydadan büyüktür. Bu durumda bayağı kesir işleminde pay, payda olarak kabul edilerek, mirasçılar 24 hisse üzerinden değil, 27 payda üzerinden $3,4,16,4$ hisse alacaklardır. Yani problemin paydası 27 olarak kabul edilerek ölenin karısı; mirastan $3 / 24$ yerine $3 / 27$; ana, $4 / 24$ yerine 4/27; kızlar 16/24 yerine 16/27; baba ise $4 / 24$ yerine $4 / 27$ hisse alacaktır (avliyye). Görüldüğü gibi bu durumda varislerin mirastan alacakları hissclerde kısmî bir azalma olmaktadır. Soruyu soran kişi, aldığı bu cevap ile yetinmemiş, karının payının 1/8 olup olmadığımı sormuş, $\mathrm{Hz}$. Ali de karının 1/8 olan payının, mirasçıların mahfuz hisselerinden dolayı 1/9'a dönüştügünü ifade ederek hutbesine devam etmiştir. Dinleyenleri, Hz.Ali'nin üstün idrak gücüne ve pratik 
"Mesele-i Şureyhiyye" ise, yine avliyye konusuna dair bir miras hukuku problemini, Hz.Ömer tarafından H.18 yılında Kufe'ye yargıç olarak atanan ve uzun süre orada hâkimlik yapan Kadı Şureyh hallettiği için bu ismi almıştır. ${ }^{23}$

\section{d. Mesele-i Me'muniyye ${ }^{24}$}

Gönenli, bu makalesini de emeklilik döneminde, avukat ünvanıyla yazmıştır. Abbasi Hâlifesi Me'mun'un, tayin etmeden önce sınava tâbi tuttuğu hâkim adaylarına miras hukuku (feraiz) ile ilgili dipnotta detayları ile zikrettiğimiz problemi sormasından dolayı, bu problem klasik fıkıh kaynaklarında "Mesele-i Me'muniyye" olarak şöhret bulmuştur. Pek çok insanın cevap veremediği bu problemi, yargıç olması, Abbasi Halifesi Me'mun'a tavsiye edilen Yahya b. Eksem çözmüş ve Halife'den takdir görmüşsürr. ${ }^{25}$

zekasına hayran bırakan bu diyalog minberde gerçekleştiği için, bu problem klasik fıkıh kaynaklarında "mesele-i minberiyye" başlığı ile yer almışırır.

Bu miras hukuku probleminde özet olarak: Vefat eden ve mirasçı olarak kocası, annesi, iki tane ana-baba bir kız kardeşi, iki tane de ana bir kız kardeşi bulunan bir kişinin mirasının nasıl taksim edileceği sonılmaktadır. Feraiz hükümlerine görc koca; terekeden $\mathrm{I} / 2$; ana $1 / 6$; ana - baba bir kız kardeşler $2 / 3$; ana bir $\mathrm{k} 1 z$ kardeşler ise $1 / 3$ pay alacaklardır. Buna göre işlem yapıldığında problemin sonucu; $1 / 2(3)+1 / 6(1)+2 / 3(2)+$ $1 / 3(2)=3 / 6+1 / 6+4 / 6+2 / 6=10 / 6$ olmaktadır. Aynen yukandaki önekte olduğ gibi, bu bayağı kesir işleminde de pay, paydadan büyük olmaktadır. Bu durumda payların toplamı olan 10, payda kabul cdilir ve mirasçıların payları 10 payda üzerinden taksim edilir (avliyye). Görüldüğü gibi bu örnek olayda da tabiî olarak bütün mirasçıların mirastaki hisselerinde nisbî bir azalma olmaktadır. Kadı Şureyh'in bu taksiminden memnun olmayan mirasçı koca, dolaştığı her yerde, konunun inccliğini bilen-bilmeyen herkese "mirasçı olarak çocuğunu veya oğlunun çocuğunu bırakmaksızın ölen bir kadının, sağ kalan kocasının mirastaki hissesinin ne kadar olduğunu" sorarak aldığı 1/2 cevabına karşılık da: Kadı Şureyh, 1/2 değil, 1/3 bile vermedi diyerek dedi-kodu yapmaya başlamıştır. Bu durumdan haberdar olan Kadı Şureyh, bu kişiyi tazir ve te'dip etmiş ve Hz. Ömer'in uygulamasını kastederek "bu hükmün, kendisinden önce âdil, salih ve mütıaki bir imam tarafından verildiğini" ifade etmiştir. Iş̧te bu diyaloga nispet edilerek de bu probleme de "Mesele-i Şureyhiyye" denilmiştir. Bu makalesinde Merhum Gönenli bu iki konuyu örneklcyerek anlatmıştır. Ankara Barosu Dergisi, Sayı 6, 1953, ss. 487-496.

A Vefat etmiş mirasçı olarak babası B'yi, annesi C'yi ve iki kızı D ve E'yi bırakmıştır. Ancak tereke taksim edilmeden önce kız (D) da vefat etmiştir. Miras nasıl taksim edilecektir? Yahya b. Akscm, Me'mun'a, ilk ölen (A)'nın bayan mı yoksa erkck mi olduğunu sorunca, Halife Me'mun, bu ayrıntıyı soran kişinin, problemin inceliğini kavradığını, problemi de çözebileceğini ifade ederek memnuniyctini izhar ile Yahya'yı Basra'ya hâkim tayin etmiştir.

Tereke taksim edilmeden önce kız ölmese idi, problemin çözümü gayet basit idi. Baba 1/6; anne 1/6, kızlar da 2/3 olmak üzere 6 payda üzerinden paylarını alacaklardı. Ancak kız (D), tcreke taksiminden önce öldüğüne göre, kendisine intikal cden mirastaki 2 payın, D'nin varislerine verilmesi gerekir. Bu durumda yeni bir taksim işlemi yapmak ve sonra iki meseleyi birleştirmek ve genel ortak paydayı tespit ederck bütün mirasçılara 
Cumhuriyet dönemindeki bütün memuriyet hayatını Yargıtay'da geçiren Mehmet Gönenli, 26.09.1945 tarihinde Yargıtay II. Başkanlığı'na atanmıştır. 13 Temmuz 1947 tarihine kadar bu görevde kalmış, ${ }^{26}$ bu tarihte ise yaş haddini doldurduğundan emekliye ayrılmıştır. Mehmet Gönenli'nin emekli olmadan önceki son görev unvanı ise "Yargıtay İkinci Başkanı"dır. ${ }^{27}$ Mehmet Gönenli, 1947 yılında emekliye ayrıldıktan sonra boş durmamış, mesaisine devam ederek İslâm Hukuku meraklılarına özel dersler vermiştir. Ayrica 1956 yılından 30 Haziran 1964 tarihine kadar fahrî olarak Ankara İmam-Hatip Lisesi'nde Tefsir, Fıkıh ve Fıkıh Usâlü derslerini okutmuştur. ${ }^{28}$

\section{Vefatı}

Mehmet Gönenli, 11 Haziran 1965 Cuma gününün gecesinde geçirdiği bir kalp krizi sonucu Hakk'ın rahmetine kavuşmuştur. Cumartesi günü ise Ankara Hacı Bayram Camii'nde ögle namazını müteakiben meslek ve mesai arkadaşları ile öğrencilerinin de bulunduğu kalabalık bir cemaat tarafından kılınan cenaze namazından sonra, gözyaşları ile Cebeci'deki ebedî istirahatgâhına tevdî edilmiştir. ${ }^{29}$ Vefatından sonra biri Diyanet İşleri Başkanlığı Dergisi'nde ${ }^{30}$ diğeri ise Adalet Bakanlığı''nca yayımlanan Adalet Dergisi'nde olmak üzere mesai arkadaşları tarafından yazılan iki tanıtma ve taziye yazısı neşredilmiştir. ${ }^{31}$

Gönenli Mehmet Efendi merhumun vefatıyla İslâm Hukuku, önemli bir mütehassıs âlimini daha kaybetmiştir. Yeri zor doldurulabilecek bu âlimin vefâtı, hukuk camiası ve milletimiz için büyük bir kayıp olmuştur.

paylarını ayrı ayrı vermek gerekir. Buna İslâm miras hukukunda münâsaha denilmektedir. Ancak, D'nin mirasçılarının tam olarak tespiti için A'nın kadın mı, crkek mi olduğunun tespiti çok önemlidir. Çünkü A'nın erkek olması durumunda $B$. kendisinin (D'nin) baba tarafından dedesi olacağı için miraş̧ı olacak; kadın olması durumunda ise anne tarafından dedesi olacağı için zevil erham statüsünde olacak ve mahfuz hissesi olanlar ve asabeler mirastaki hisselerini aldıktan sonra mirasçı olabilecektir. Örnek olayda ise farz sahipleri bulunduğu için (ana-baba bir kız kardeş E) anne tarafından dede miraş̧ı olamamaktadır.

İşte bu makalesinde Merhum Gönenli, İslâm miras hukukunun çok önemli problemini (münâsaha) değişik alternatifleri dikkate alarak analiz etmiştir.

27 Adalet Bakanlığındaki Şahsî Sicil Dosyası, s. 6; aynca, Köseoğlu, agm., s.795.

28 Köscoğlu, agm., s.796.

2) Köseoğlu, agm., s.796.

30) Ali Himmet Berki, "Memleketimiz Kıymetli Evlâdından Birini Daha Kaybetti". Diyanet İşleri Başkanlığı Dergisi, c.IV, saỵı, 7-8. Temmuz- Ağustos 1965, ss.120-121.

${ }^{31}$ Cemalettin Köscoğlu, "Büyük Bir Hukuk Bilgininin Ölümü” Adalet Dergisi, Yıl:56, Sayı 7-8, (Temmuz-Ağustos 1965) ss. 795-796. 


\section{AHKÂM-I ŞAHSIYYE KOMISYONU TARAFINIDAN TESPIT EDILEN KANUN MADDELERİ*}

Madde 1- Nişanlanmak, nikahlanmak değildir. Nişanlandıktan sonra rücû eden tarafi, nikah akdine zorlamak için dava açılamaz. Nişanlandıktan sonra nikahtan kaçınma (imtinâ) durumunda tazminat verilecey̆ine dair şartın bir hükmü yoktur.

Madde 2- Nişanlandıktan sonra taraflardan biri nikahtan kaçınır veya vefat ederse, nişanlı erkeğin (hâtıb)'ın, mchire mahsûben vermiş olduğu eşya mevcut ise aynen; telef olmuşsa kıymet bedeli (tebeddülen) geri alınabilir. Ancak tarafların birbirlerine verdiği hediyeler hakkında hibe ile ilgili hükümler geçerlidir.

Madde 3- Nişanlı erkek (hâtıb) 18, nişanlı kadın (mahtûbe) ise 17 yaşını bitirmedikçe evlenemezler.

Madde 4- 12 yaşını bitirmemiş erkek ve kız çocuklar hiçbir kişi tarafindan evlendirilemez.

Madde 5- 18 yaşımı bitirmemiş erkek ve 17 yaşını bitirmemiş kadının fizikî durumu evliliğe müsait ise veya zorunlu bir durum (zarûret) söz. konusu ise hâkim, evliliğe istisnaî olarak izin verebilir.

Madde 6- Beşinci maddeye göre hâkimin istisnaî olarak evliliğe izin vermesi için, velinin izninin bulunması şarttır.

Madde 7- Evlenme yaşına giren ancak rüşt yaşına ulaşmayan kadın ve erkeğin (hâtıb ve mahtûbenin), velilerinin bilgisi olmaksızın evlenmek üzcre müracaatta bulunmaları hâlinde hâkim, durumu velilerine tebliğ eder. Veli, tebliğ tarihinden itibaren 10 gün içinde itiraz etmediği veya itirazı geçerli görülmediği takdirde evliliklerine izin verir.

Madde 8- Mecnûn ve mecnûne (akıl hastası kadmn ve erkek) hiçbir kişi taraf indan evlendirilemez.

Madde 9- Bunak (ma'tûh) ile bunama derecesinde ne yaptığını bilmeyen kişilerin (belâhet ashâbınnn) evliliğinde ilave şart olarak velilerin izni zorunludur.

Madde 10- Evlenme aktinde veli; sıra ile evlenecek kişinin babası, annesi, babasının babası, annesinin babası, amcası ve dayısıdır.

Madde 11-Başkası ile nikahlı olan (menkûhe) veya boşandıktan sonra iddet bekleyen ( $m$ u'tedde) kadın ile evlenmek yasaktır.

Madde 12- Bir tek kadın ile evlilik temel ilkedir. Bu nedenle ikinci bir kadın ile evlenmek isteyen erkeğin, haklı gerekçesini (zarûretini) ve eşler arasında adalete ehliyetli olduğunu ispat edip hâkimin iznini almadıkça, birden fazla kadınla evlenmesi yasaktır.

- Cerîde-i Adliyye'nin 1340 tarih ve 25, 26, 27 ve 28. sayllarında yer alan orijinal mctin, aynen latinize edilme yerine, anlaşılmasını kolaylaştırmak için tarafımızdan sadeleştirilmiştir. 
Madde 13- Aralarında evlenme engeli doğuracak derecede kan veya süt akrabalığı bulunan iki kadını birlikte nikahlamak yasaktır. ${ }^{32}$

Madde 14- Aralarında evlenme engeli doguracak derecede kan (nesep) akrabalığı bulunan ( $z \hat{\imath}$ rahm-i mahrem) kadın ve erkeğin birbiriyle evlenmesi sürekli olarak (ebediyyen) yasaktır.

Buna göre erkeğin;

a. annesi ve nineleri (usûlï) ile,

b. kızları ve torunları $(f u r u ̂ u)$ ile,

c. ana-baba bir, baba bir veya ana bir kız kardeşleri ve bunların kızları (ana ve babanın furûu ve bunların furûu) ile, ve

d. halası ve teyzesi (ana ve baba tarafından dedelerin sadece birinci derece furûu) ile evlenmesi sürekli olarak yasaktır.

Madde 15- Aralarında 14. maddede zikredilen derecelerde süt akrabalı ̆̆ evlenmesi sürekli olarak yasaktır.

Madde 16- Erkeğin, kendisi ile arasında sihrî akrabalık bulunan kadınlarla evlenmesi sürekli olarak yasaktır. Buna göre bir erkeğin;

a. gelini; yani, oğlunun, ve oğlunun oğlunun ... eşi, (furûu'nun eşi) ile,

b. eşinin annesi ve nineleri (eşinin usûlü) ile,

c. üvey annesi (babasının ve dedelerin eşleri) ile,

d. üvey kızları, yani eşinin başka kocadan olma kızları (eşinin furûu) ile evlenmesi sürekli olarak yasaktır.

Ancak bu maddenin "d" fıkrasında zikredilen yasağın doğması için, evlenme aktinden sonra fiilî birleşme (takarrub) nin olması gerekir.

Madde 17- Kaynağını fasit bir evlilikten alan fiilî birleşme (takarrub), sıhriyyetten doğan evlenme engellerini doğurur.

Madde 18- Evlenme akdinin icrasından önce durum, evlenecek kadının (mahtûbe) ikamet ettiği köy ve mahallenin ihtiyar heyeti (muhtarlı̆̆ı) veya devletçe bu tür meseleler için görevlendirilecek özel bir memur marifetiyle ve her yörenin (mahallin) âdetine göre, uygun şekillerde ilân edilir. Evlenecek erkek ( $h a \hat{a} t b$ ) başka bir köy ve mahallede ikamet ediyorsa, o yerin ihtiyar heyetinden, evlenmesine mani bir durumu bulunmadı̆̆ına dair bir belge (ilmu haber) ibraz eder.

Madde 19- Evlenecek tarafların belgelerine göre, işbu kanunun üçüncü maddesinde belirlenen evlenme yaşma henüz girmemiş olanlarmn veya 5., 6 . ve 9. maddeler gereği velilerinin izni ile akitlerine öncelikle (evvel emirde) hâkim tarafından izin verilmesi gerekli olanların; ya da akitlerinin icrasına

32 Birbirine çok yakın akrabaları aynı nikahta toplama yasağının kapsamı konusunda fakihler tarafından şöyle bir genel kural kabul edilmiştir. Ayn nikah altındal toplanmak istenen iki kadından birisi erkek farzedildiği takdirde; bunlar arasındaki süt veya nescp akrabalığının derecesi, birbirleriyle evlenmeye engel teşkil ediyorsa, üçüncü kişinin bu kadınların ikisini nikahlaması mümkün değildir. (el-Kâsânî, Bedâiu's-Sanâi fí Terribi'sŞerâi'. II/262; İbnu'l-Hümam. Fethu'l-Kadîr. II/364) 
diğer hukukî engel durumlar (mâni sebepler) bulunanların, yasal işlemleri tamamlanmadıkça ilânlarına izin verilmez.

Yedinci madde gereği, evlenme yaşına ulaşmasına rağmen henüz rüşt yaşına girmeyen (sinn-i rüste reşîd olmayan) kadın ve erkek, velilerinin izin ve muvafakatini gösteren belgeleri ibraz ederler ve evlenme akdinin icrasına mani başka sebepler de bulunmazsa durum, ihtiyar heyeti marifetiyle doğrudan ( $r e$ 'sen) ilân edilebilir ve hâkim tarafından veli'ye tebliğ edilmesine gerek kalmaz. Eğer bu izin ve muvafakat belgesi (vesîkast) ihtiyar heyetine ibraz edilememiş ise durum, yedinci maddeye uyularak hâkim tarafından veli'ye tebliğ edilir.

Madde 20- İhtiyar heyetinin ilândan kaçınması (imtinâ) halinde iki taraf veya taraflardan birisi, köy veya mahallenin bağlı bulunduğu ilçe hâkimine müracaat ederek ilân hakkında bir karar alınmasını isteyebilir.

Madde 21- İlan tarihinin bir gün sonrasından (ferdâsından) itibaren tam on gün geçmedikçe nikah akdi yapılmaz.

Madde 22- Meşrû ve makul gerekçelerle (esbâb-ı mûcibeye mebnî), nişanlıların evlenme akdinin geciktirilmesi sakıncalı görülürse, hâkimin müsaadesiyle ilân edilemeyeceği (sarf-ı nazar olunabileceği) gibi, ilân süresi de kısaltılabilir.

Made 23- İlgililerin, süresi içinde ilana yapabilecekleri itirazlar, ilânı yerine getiren köy veya mahallenin bağlı bulunduğu ilçe hâkimine gönderilir. Bu itirazlardan sadece akde taraf olan nişanlıların (hâtıb ve mahtûbenin) henüz evlenme akdine chil olmadıkları veya aralarında evliliğe mani yasal sebepler bulunduğuna dair olan iddialar dinlenir (mesmû' olur), bunun dışındakiler dikkate alınmaz.

Madde 24- İtirazlar üzerine mahkeme, 15 gün içinde incelemelerini tamamlamak ve davayı sonuçlandırarak karar vermek zorundadır.

Madde 25- İlân tarihinden itibaren bir y1l içinde evlenme akdinin yapılmaması (nikahın akdedilmemesi) durumunda ilân hükümsüz olur.

Madde 26- İlân süresi içinde hiçbir itiraz olmamış veya hâkim, itirazları kanunen dikkate alınabilir nitelikte görmemişse evlenme akdi yapılır. Akit sırasında taraflardan (hâtıb ve mahtûbe'den) birinin ikametgahının bağlı bulunduğu ilçe hâkimi veya bu hâkimin özel bir belge (izin nâme) ile yetki verdiği nâib ya da devletçe bu tür akitlerin tescili için görevlendirilecek özel görevli, (me'mûr-i mahsûs) hazır bulunarak evlenme belgesini (akit nâme'yi) tanzim ve tescil eder.

Madde 27- Evlilik akdi sırasında, şahitlik ehliyetini haiz (mükellef) en az iki şahidin bulunması, nikahın geçerliliğinde (sthhatinde) şarttır. Evlilik akdinde taraf olan kadın ve erkeğin usûl ve furûu da şahitlik yapabilir.

Madde 28- Nikah, evlenme dairesinde (meclissinde) iki tarafın veya vekillerinin icap ve kabûlü ile akdedilir.

Madde 29- Evlilik, şarta talik veya gelecek zamana izafe edilemez.

Madde 30- Evlenme akdinin bağlayıcı olması için (lüzûm), evlenecek kişilerin denkliği (kefâet) şarttır. Bu nedenle velinin kendi izin ve 
muvafakatine ihtiyaç bulunan maddelerde denkliğin bulunmadığını (adem-i kefâet) gerekçe göstererck evliliğe itiraz hakkı vardır.

Madde 31- Akit sırasında denklik şart koşulmuş veya koca, evlenmeden önce denk olduğunu beyan etmiş ancak, daha sonra denkliğin bulunmadığı sabit olmuşsa veli, hâkime müracaat ederek nikahı feshettirebilir.

Madde 32- Denkliğin bulunmaması sebebiyle hâkim, nikahı ancak kadın hamile olmadan önce (hamlin zuhurundan önce) fesheder.

Madde 33- Velinin, dolaylı olarak (delâleten) ve açık bir ifade ile (sarâhaten) denkliğin bulunmamasına rızası, fesih hakkını düşürür.

Madde 34- Daha yakın veli gaib iken, derece olarak ondan uzak olan velinin rızası, daha yakın olan velinin itiraz hakkını düşürür. Dereceleri eşit olan velilerden birisinin rızası, diğgerlerin itiraz hakkını düşürür ${ }^{33}$

Madde 35- 12 yaşını bitirmemiş olan erkek ve kız çocuklarının, kim tarafindan olursa olsun akdettiği nikah hükümsüz (bâttl) dür.

Madde 36- Hâkimin sözlï (şifahî) müsaadesi ve velînin izni olmaksızın 18 yaşını bitirmiş erkek (hâtıb) ve 17 yaşını doldurmamış kadının (mahtûbe), yaptığı evlenme akdi geçersiz (fasit) dir. ${ }^{34}$

Madde 37- Evlenme yaşına girmiş ancak rüşt yaşına ulaşmamış olan kadın ve erkeğin (hâtıb-mahtûbe), işbu Kanunun yedinci maddesine göre velîlerinin bilgisi ve hâkimin izni olmaksızın evlilikleri geçerli (sahîh) olmakla beraber bağlayıcı (lâzım) değildir.

Madde 38- Akıl hastası olan (mecnûn ve mecnûne) kadın ve erkeğin kim tarafından yapılırsa yapılsın evlilik akdi hükümsüz (bâtıl) dür.

Madde 39- Bunak (ma'tûh) ile bunama (ateh) derecesinde ne yaptığını bilemeyecek durumda olan kişilerin (ashâb-ı belâhet) evlenme akdi geçersiz. (fâsit) dir.

Madde 40- Başkası ile nikahlı olan (menkûhe) veya iddet bekleyen (mu'tedde) kadın ile evlilik hükümsüz (bâtll) dür.

Madde 41- On ikinci maddede sayılan şartlara uygun olarak hâkimin izni alınmaksızın akdedilen ikinci evlilik akdi (nikâh) hükümsüzdür.

Madde 42- On üçüncü madde gereği aynı nikahta birleştirilmeleri yasak olan iki kadından birisi ile evli iken, ikinci ile yapılan evlenme akdi hükümsüzdür.

Madde 43- Kendileriyle evlenilmesi işbu Kanunun 14, 15. ve 16. maddelerinde yasaklanan kadinlardan herhangi birisi ile yapılan evlenme akdi hükümsüzdür.

33 Kanun taslağının 1-34. maddeleri Cerîde-i Adliyye'nin Ağustos 1340 tarih ve 25. sayısının 32-35 (889-891) sayfalarında neşredilmiştir.

31 Cerîde-i Adliyye' nin 26. sayısında neşredilen bu taslak maddelerin başında "Ahkâm-ı Şahstyye Komisyonu"nun Hact Adil Bey başkanlı̆̆ında; Şevket Muammer Raşit. Şukrü Kava, Ahmet Samim ve (Ömer Nasuhi'nin sağlık sebebiyle (̧ekilmesi üzerine) Kemal Auff Bey'lerin iştirakiyle 17 Haziran 1340 tarihinden beri celselerine devam etmekte" olduğu ifade edilmektedir. 
Madde 44- Şahit bulundurulmaksızın yapılan evlenme akdi, eğer bu kanunun 26. maddesinde gösterildiği gibi, hâkim veya naibi ya da devletçe bu tür akitlerin tescili ile görevlendirilmiş bir memur huzurunda akdedilmemiş ise hükümsüz (bâtll); bu görevlilerden birisi hazır iken yapılmış ise geçersiz (fâsit) dir.

Madde 45-26. madde gereği hâkimin veya belge (izin nâme) vermeye yetki verdiği naibinin, ya da devletçe bu tür akitlerin tescili ile görevlendirilmiş olan memurun huzurunda yapılmayan evlenme akitleri hükümsüzdür.

Madde 46- Hayatı ve namusu gayr-i meşrû bir şekilde vukuu muhakkak ve kendince kaçınılması ve karşı konulması imkânsız bir tehdit altında evlenme akdine zorlanan eşlerden her biri, akdi feshettirebilir. Anne-babaya hürmet ve itaat tesiri altında yapılan evlenme akdinde, bu sebeple ikrah iddiası kabul edilmez (mesmû olmaz).

Madde 47- Müslüman bir kadının gayr-i müslim bir erkek ile evlenmesi hükümsüzdür.

Madde 48- Karı-kocadan birisi, eşinin şahsı ve hüviyeti (kişiliği) hakkında yanıı̧ bilgilendirilerek aldatılmış (iğfal edilmiş) ise, nikahı feshettirebilir.

Madde 49- İkrah durumunun ortadan kalkmasından (zevâlinden) veya iğfal edildiğine muttali olma tarihinden itibaren üç ay içinde (mağdur), evlenme akdini feshettirebilir. Ancak her iki durumda akit tarihinden itibaren bir yıl geçmiş ise fesih için dava açılamaz.

Madde 50- 46. ve 47. maddeler mûcebince açılabilecek fesih davası, gebelik halinde düşer.

Madde 51 - Evliliğin hükümsüzlügü veya geçersizliği (butlân ve fesât) ile ilgili salt iddia yeterli olmayıp, mahkemeye dava açılması ve karar istihsali gerekir.

Madde 52- 25, 28, 40, 42, 45 ve 47. maddeler ile 44. maddenin ilk fıkrası gereği hükümsüz kabul edilen akitlerde boşanma davası, taraflar (âkitler) ve ilgililer tarafından açılır.

Madde 53- 36 ve 37. maddeler ile 44. maddenin son fıkrası gereği geçersiz (fâsit) kabul edilen akitlerde, fesât (geçersizlik) davası taraflar (âkitler) ve ilgililer tarafından açılır.

Madde 54- 36. madde gereği geçersiz (fâsit) olan akitte velî, nikahtan sonra açıkça (sarâhaten) ve dolaylı olarak (delâleten) akde icazet vermiş veya evlenme akdine muttali olduğu tarihten itibaren bir yıl içinde itiraz etmemiş ise fesât davası düşer.

Yaşı küçük çocuğun evliliğinde, nikah akdinden sonra, fesat sebebiyle hüküm tarihinden önce ve çocuğun evlenme yaşına girmesinden itibaren 3 ay içinde fesat iddiasında bulunmadığı veya eş gebe kaldığı takdirde fesat davası düşer. 
Madde 55- Şahitsiz akdedildiğinden dolayı geçersiz (fâsit) olan evlilikte, kadının hamile olduğunun ortaya çıkması veya akit tarihinden itibaren üç yıl geçmesi durumunda fesat davası düşer.

Madde 56- 39. madde gereği fâsit olan evlilikte, velînin akitten sonra açıkça veya dolaylı olarak evliliğe icazet vermesi veya matuh ve eblehin iyileşerek kendisinin nikahı tasvip ettiğini ifade etmesi; ya da kadının hamile olması durumunda fesat davası düşer.

Madde 57- 56. ve 57. maddeler gereği, fesat davasının düşmesi hâlinde, savcıların (müddể-i umûmî), fesat (geçersizlik) iddiaları düşer. Ancak kanunî hükümleri tatbik etmeyen hâkim ve naibi ile, özel görevli memur ve âkitler (taraflar) aleyhine icra etmek zorunda olduğu kovuşturma (ta'kibât) bu hükümden müstesnadır.

Madde 58- 35, 40, 41, 42, 43 ve 47. maddeler ile 44. maddenin ilk fıkrası gereği, nikahın butlanının, savcı tarafından karı-kocanın sağlığında (hâl-i hayatında) iddia edilmesi gerekir. Karı-kocadan birisinin vefatından sonra savcı, hükümsüzlük (butlân) iddiasında bulunamaz, fakat diğer ilgililer vefattan sonra da butlan iddiasinda bulunabilirler.

Madde 59- İşbu Kanunda hükümsüz ve geçersiz (bâtll ve fâsit) kabul edilen evlilik akitlerinde butlan ve fesat davaları, doğrudan (re'sen) savcılar tarafından da açılır ve takip edilir.

Madde 60-38. maddeye dayanarak butlan iddia edilmesi durumunda, hasta iyileşip normal hâle döndükten (hâl-i sahv'e avdetten) itibaren bir yıll içinde dava açılmazsa dava düşer.

Madde 61- Bir evlenme akdinin butlan veya fesadına hüküm verildiğinde, eğer evlenme akdi, başlangıçta hâkim veya naibi, ya da devletçe bu tür akitlerin tescili için görevlendirilmiş özel memur huzurunda icra edilmiş ve karı-koca arasında fiilî birleşme (takarrub) olmuşsa, bu fiilî birleşme, nafaka ve iddet yükümlülüğü doğurur; nesep ve evlilikten doğan evlenme engelleri (hürmet-i musâhere) sabit olur, ancak eşler arasında, tevârüs cereyân etmez (birbirlerine mirasçı olamazlar).

Madde 62- Nikahın sahih olarak gerçekleşmesinden sonra kocanın, karısına mehir ve nafaka ödeme yükümlülüğü doğar ve eşlerin birbirlerine mirasçı olma hakkı sabit olur.

Madde 63- Koca, karısı için, kendi seçtiği (intihâb ettiği) yerde, bütün levazımıyla bir konut (mesken) temin etmek zorundadır.

Madde 64- Karı, kocasının tercih ettiği (intihâb ettiği) evde ikamet etmek ve başka bir memlekete gitmek istediğinde kocasıyla beraber gitmek ile yükümlüdür.

Madde 65- Koca, karısının rızası olmaksızın evinde usûl ve furûu dışındaki akrabasını iskân edemez. Karı da kocası razı olmadıkça reşit olmayan çocuklarından başka akrabasını, birlikte iskân edemez.

Madde 66- Karı-koca birbirlerine iyi davranmak, yardımcı olmak ve sadakat göstermekle yükümlüdürler. Karı, kocasına itaat etmek zorundadır.

Madde 67- Karı, kocasının soyadını (ismini) alır. 
Madde 68- Karı veya koca, ya da her ikisi, hemen veya daha sonra teslim edilmek veya ölüm veya boşama vukûunda eşit olarak paylaştırılmak (tesviye olunmak) şartıyla karşılıklı olarak (mütekâbilen) birbirine bir mal veya muayyen bir miktar (para) verilmesini taahhüt edebilirler.

Madde 69- Akit sırasında karısı için mehir ismiyle bir mal ve para taahhüt etmek isteyen koca, bunun türünü (cinsini) ve miktarını açı olarak belirtmek zorundadır. Belirlenmeyen ve açıkça isim olarak zikredilmeyen mehir iddiaları dinlenmez (mesmû' olmaz).

Madde 70- Kızını evlendiren ana-babanın veya akrabasının, kocadan para (akçe) ve diğer şeyler almaları yasaktır.

Madde 71 - Karı ve koca, birbirinin tedavi edilemeyen (mâni-i takrîr) hastalıklardan birisine tutulduğunu öğrendiğinde, hâkime müracaat ederek yargı yoluyla ayrılma (tefrîk) talebinde bulunabilir. Böyle bir hastalığın varlığına nikahtan önce muttali olan karı veya kocanın, hastalığın (ayıbın) devamı hâlinde nikahtan sonra da tefrik talebinde bulunma hakları vardır. Ancak karı-koca arasında fiilî birleşme olduktan sonra ortaya çıkan bu tür (kâbil) ayıp sebebiyle tefrik davası dinlenmez.

Madde 72- Bir önceki maddede var olduğu iddia edilen hastalığın tedavisi mümkün değilse, (hastalık kâbil-i zevâl değilse) hâkim, karı-kocanın arasını hemen (derhâl) tefrik eder, eğer tedavi edilebilir bir hastalık ise, tefrik talebi tarihinden itibaren tefriki bir yıl tecil eder. Bu süre içinde hastalık iyileşmediği ve ilgili de talebinde ısrar ettiği takdirde mahkeme kararıyla nikah feshedilir.

Madde 73- Karı-kocadan birisi, eşinde kendisinin veya neslinin hayat ve sağlığını ciddî biçimde tehlikeye sokacak bir hastalığın mevcut olduğuna muttali olduğunda nikahın feshini talep edebilir.

Madde 74- Nikah akdinden sonra eşlerden birinin akıl hastalığına yakalanması (tecennün) durumunda, diğeri hâkime müracaat ederck eşinden tefrikini talep eder. Hâkim, tefriki bir yıl süre ile tecil eder. Bu süre içinde akıl hastalığı iyileşmediği (cinnet zâil olmadığı) ve ilgili de talebinde ısrar ettiği takdirde tefrike hükmeder.

Madde 75- Tefrik sebeplerinden birisi sebebi ile ayrılan eşlerin, akdi yenilemeleri durumunda, bu ikinci evlilikte de eşlerin, aynı sebebi gerekçe göstererek tefrik davası açma hakları yoktur.

Madde 76- Kabul edilebilir hiçbir sebep ve özür bulunmaksızın terk edilen karı veya koca, hâkime müracaat ederck şikayette bulunduğunda hâkim, gerekli soruşturma ve incelemeyi (tahkikât) yaptıktan sonra iddiayı haklı görürse davalıya (müiddeâ alcyh) gerekli telkin ve uyarıları yaparak eşlerin ortak hayatı yeniden tesis etmelerini emreder. Bu tarihten itibaren en az bir yıl sonra davacı taraf (mü̈dể), hâkime müracaat ederek diğer tarafın kendisini terk etmeye devam ettiğini iddia ve ispat ederek tefrikini talep ederse, hâkim, aralarını tefrik eder.

Madde 77- Eşlerden biri, kabul edilebilir bir özür veya sebeple ya da bilinmeyen bir sebeple, kaybolur veya kendisinden haber alınmazsa 
(tağayyub ve ihtifâ), diğer eş hâkime müracaat ederek tefrik talebinde bulunduğunda, eğer kaybolan eş koca ise ve nafaka bırakmaksızın kaybolmuş ve kayıp tarihinden itibaren bir yıl geçmiş ise hâkim; kocanın ortaya çıkarak (ispat-1 vücûd ederek) ortak aile hayatına (hayât-ı müşterekeye) dönmesi gerektiğini uygun vasıtalarla ilan eder. Davalı (gâib, müddeâ aleyh) bu süre içinde ispat-1 vücûd etmediği ve davacı da tefrik talebinde ısrar ettiği takdirde hâkim, aralarını tefrike hükmeder. Ancak gâib, koca olup nafaka da bırakmış ise, ispat-1 vücûd için hâkimin tayin edeceği süre, bir yıla kadar uzatılabilir.

Madde 78- Eşlerden birisinin, en az iki yıldan beri sağ olup olmadığı bilinmiyorsa (mefkûd), diğer taraf hâkime müracaat ederek tefrik talebinde bulunabilir. Hâkim, gerekli soruşturma ve incelemeyi (tahkikatt) yaptıktan sonra bir yıl daha te'cil eder. İşbu süre içinde karı veya koca ortaya çıkmadığı (ispat-ı vücûd etmediği) veya kendisinden bir haber alınamadığı ve davacı da tefrik talebinde ısrar ettiği takdirde tarafları tefrik eder, ancak mefkûd olan eş koca olup nafaka bırakmış ise hâkim, ispat-ı vücûd için belirleyeccği süreyi iki yıla kadar uzatabilir..$^{35}$

Madde 79- Vefatına hükmedilen mefkûd'un karısı, hâkime müracaat ederek ayrıca tefrik kararı alınmasını talep edebilir. Bu takdirde 77 ve 78 . maddelere göre tefrikine hükmedilen (karı) başka bir erkek ile evlendikten sonra, mefkûd olan ilk kocanın ortaya çıkması (zuhûru), son nikahın feshedilmesini gerektirmez. Vefatına hükmedilen kişinin karısı, mefkûdiyet sebebiyle tefrik karanı almaksızın (istihsal etmeksizin) başka bir erkekle evlendikten sonra, ilk kocasının hayatta olduğu kesinleşirse, ilgililerin davası ve hâkimin kararı ile ikinci nikah feshedilir. ${ }^{36}$

Madde 80- Taraflardan biri, namus ve şerefi ihlâl eden bir suçtan mahkum olursa, diğer taraf mahkemeye başvurarak tefrik davası açabilir.

Madde 81- Eşlerden birinin, diğerinin hayatına kastettiği kesinleştiği (sabit olduğu) takdirde, diğer eş tefrik davası açabilir.

Madde 82- Eşlerden biri diğerine, evlilik rabıtasının devam etmesine maddeten imkân birakmayacak bir şekilde eziyet ve işkence (zulüm ve $e z \hat{a}$ ) ettiği takdirde, diğer eş tarafından tefrik davası açılabilir.

Madde 83- On ikinci maddeye göre, ikinci eş olmak üzere evlenen kadının, akit sırasında, nikahlandığı kocasının kendisinden önce nikahlı başka bir eşinin daha bulunduğunu bildiği ve buna sarih olarak rıza

35 Kanunu Ilazırlama Komisyonu, daha sonra gönderdiği rapor ile, bu maddenin sonuna

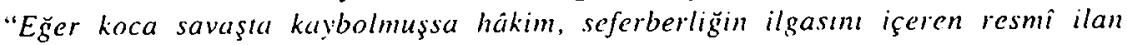
rarihinden itibaren iki yl geçtikten sonra tefrike hükmeder" fıkrasının ilave edildiğini jfade etmiştir.

36 Kanunu Hazırlama Komisyonu. daha sonra gönderdiği rapor ile, bu 79. maddenin sonuna "şu kadar ki, ilk kocanın veya karmun hükmen de ğil gerçekten vefat etmesi durumunda fesih davası dinlenmez" fikrası ilave edilmiştir.

Kanun taslağının 35-79. maddeleri, Cerîde-i Adliyye nin Eylül 1340 tarih ve 3. senc 26. sayısımın 17-21 (953-957) sayfalarında neşredilmiştir. 
gösterdiği koca tarafından ispat edilmez ve eş (karl) tefrikini talep ederse hâkim, aralarını tefrik eder.

Madde 84- Tek eş ile evli olan kişinin, on ikinci madde mûcebince ikinci bir eş ile evlenmesi hâlinde, ilk eşi, sadece bu ikinci evliliği gerekçe göstererek tefrik davası açabilir.

Madde 85- Eşlerden her birinin, diğerine karşı kasıtlı olarak saldırgan davranması (maddî şiddet kullanması); ve hakareti alışkanlık (i'tiyâd) haline getirmesi; aile hayatında ortak olduğu görev ve sorumluluklarını bile bile yerine getirmekten kaçınması; ailenin namus, şeref ve ismetini ayakları altına serecek (pây-ı mâl edecek) kötü hareket ve davranışta bulunması ve aileyi geçim sıkıntısına sokacak aşırı israf ve savurganlık gibi sebeplerden dolayı, eşler arasında, iyi ilişkilerin veya evlilik rabıtasının devamını imkânsız kılan çekişme ve şiddetli geçimsizlik (nizâ' ve şikâk) zuhur ederse, taraflardan biri mahkemeye müracaat ederek tefrik talebinde bulunabilir.

Madde 86- 85. maddede açıklanan sebeplerle koca, karısını boşayabilir. Ancak boşamanın (icâb-ı talâkın), hâkim veya ...nci madde ${ }^{37}$ hükümlerine göre hâkim tarafından teşkil edilen hakem heyetinin huzurunda olması (îkâı) şartır.

Madde 87- İstediği zaman kendi kendisini boşamak üzere kocası tarafından kendisine boşama hak ve yetkisi verilen (tefvîd-i talâk) karı, 85 . maddede açıklanan sebeplerden dolayı ve ancak hâkim huzurunda veya ...nci madde $^{38}$ hükümlerine göre hâkim tarafından teşkil edilen hakem heyeti huzurunda kendi kendisini boşayabilir.

Madde $88-71,72,74,75,76,77,78,79,80,81,82,83,84$ ve 85 . maddelerde belirtilen ayrılma sebeplerinden birisiyle hâkime başvurmaksızın, eşini hâkim veya hakem topluluğu (heyet-i hakemiyye) huzurunda boşayan kocaya, hâkim tarafından gerekli nasihat ve ikazlar yapılır ve kendisinden, boşama tarihinden itibaren üç aylık süre içinde yaptığı işlemin (tasarrufunun) doğuracağ ${ }_{1}$ sonuçları düşünmesi istenir. Kocanın bu süre içinde eşine dönme (rücû') hakkı vardır.

Madde 89- Koca üç ay içinde eşine dönerse, aralarında mevcut olan evlilik devam eder. Kocanın, bu hususta eşinin irade beyanını (rızasını) alması zorunlu değildir.

Madde 90- Koca, hâkimin huzurunda gerçekleştirdiği boşamanın (talâk) tescilinde ısrar eder veya boşama tarihinden itibaren üç aylık süre içinde eşine rücû' etmezse, rücû' hakkı düşer ve hâkim aralarını tefrik eder.

Madde 91- 89. madde hükmüne göre, birinci boşamadan sonra rücû' etmek geçerli (sahih) olduğu gibi; ikinci boşamadan sonra da rücû' geçerlidir (sahihtir). Ancak üçüncü boşama ile rücû' hakkı, kesin olarak düştüğü gibi, nikah akdine de izin yoktur.

\footnotetext{
${ }^{37}$ Bu maddenin bilahare tedvin edileceği jfade edilmektcdir. Bkz. Ceríde-i Adliyve. Sayı 27, s. 1034

${ }^{38}$ Bu maddenin bilahare tedvin edileceği ifade edilmektedir. Bkz. Cerîde-i Adliyye, Sayı 27, s. 1034
} 
Madde 92- Yukarıdaki maddelerin hükümlerine göre hâkimin tefriki, evlilik bağını (zevciyyet) ortadan kaldırır. Şu kadar var ki, bir veya iki tefrik, nikahı yenilemeye engel teşkil etmez. Ancak üç kez tefrikten sonra, nikah akdine izin verilmez.

Madde 93- Koca sahih bir akit ile evli olduğu eşini, fiilî birleşmeden (takarrub) önce 85 . madde hükümlerine göre boşarsa, nikahın yenilenmesi (tecdîd-i nikâh) gerekir.

Madde 94- Boşama (talâk) veya yargı kararı ile ayrılma (tefrik) davasını reşit olan karı veya koca açabilir. Şu kadar ki, 12 yaşını bitirmiş olarak velîlerinin muvafakati ve hâkimin istisnaî olarak verdiği izin ile evlenmiş olanların boşama (talâk) veya tefrik davaları, velîlerinin iznine bağlıdır. Evlenme yaşında olmakla beraber rüşt yaşına girmeyenlerin (sinn-i rüşde reşîd olmayanların), velîlerinin bilgisi olmaksızın talâk veya tefrik talebiyle müracaat etmeleri hâlinde hâkim, durumu velîlerine tebliğ eder, velî, tebliğ tarihinden itibaren 10 gün içinde itiraz etmediği veya itirazı yerinde (geçerli) görülmediği takdirde davayı dinler.

Madde 95- Akıl hastasının (mecnûn), sarhoşun ve iradesine maddî baskı yapılan kişinin (mükreh) boşaması geçerli değildir.

Madde 96- Bunak (ma'tûh) ile, bunama derecesinde olan eblehlerin (ashâb-ı belâhet) tefrik davası, velîlerinin munzam muvafakati (ilave onayı) olmadıkça dinlenmez.

Madde 97- Sahih bir akit ile evlenip fiilen birleştikten sonra (takarrub) boşama, fesih veya tefrik sebebiyle kocasından ayrılan ve hayız gören veya âdetten kesilen (sinn-i iyâs'a ulaşan) kadınların iddet müddeti 90 gündür.

Madde 98-97. maddenin hükmü, 61. maddeye göre bâtıl veya fâsit bir evlenme akdinden sonra frilen birleşen ancak fesih ve tefrik edilen veya kocası vefat eden kadınlar için de geçerlidir.

Madde 99- Sahih bir nikah akdi ile evli olduğu eşi vefat eden kadının iddet süresi 130 gündür.

Madde 100- Sahih bir nikah akdi ile evlenip hamile iken talâk, fesih veya tefrik sebebiyle kocasından ayrılan veya kocası vefat eden kadının iddeti, doğum yapıncaya (hamlini vazedinceye) kadardır. Düşük doğum yaptığı iddia edildiği ve bu durum da tıbben ispat edildiği takdirde hamilelik iddeti biter. İşbu maddenin hükmü, 61. madde gereği bâtıl veya fâsit bir nikah akdi ile evlenmiş olup da tefrik edilen veya kocası vefat eden kadınlar için de geçerlidir.

Madde 101- 97, 98, 99, ve 100. maddelerde zikredilen süreler geçmedikçe (iddet bekleyen) kadın, başka bir erkek ile evlenemez.

Madde 102- Yukarıdaki maddelerde belirtilen iddet süresinin başlangıcı, boşamanın gerçekleştiği veya fesih ve tefrik, ya da kocanın vefat tarihidir, velev ki, kadın bu durumlara muttali olmasın.

Madde 103- Sahih evlenme akdinde veya 61. maddeye göre fâsit ve bâtıl kabul edilen akitlerde boşama, fesih veya tefrik, fiilî birleşmeden önce gerçekleşirse, iddet gerekmez. 
Madde 104- 88. madde gereği eşine rücû' etmek üzere kendisine üç aylık süre tanınan koca, eşine rücû' etmeden önce bu süre içinde vefat ederse, kadının vefat iddeti beklemesi gerekir.

Hamileliğin alt sınırı (asgarî süresi) 180, üst sınırı (azamî süresi) ise 300 gündür.

Madde 105- Vefat veya boşamada hamilelik iddetinin azamî süresi, vefat veya boşamanın meydana geldiği tarihten itibaren; tefrik davası hâlindeki hamileliğin üst sınırı (azamî süresi) ise Kanunun ...nci maddesi ${ }^{39}$ hükmüne göre, hâkim tarafların ayrı ayrı meskenlerde ikâmet etmelerini emretmiş ise bu tarihten; eğer böyle bir emir yoksa tefrik hükmü verildiği tarihten itibaren 300 gündür.

Madde 106- Boşama, fesih veya tefrik sebebiyle kocasından ayrılan kadının, kocasının soyadını (ismini) taşıması yasaktır. Bu durumda kadın, yeniden kendi aile ismini alır. ${ }^{40}$

Madde 107-103, 104, 105 ve 106. maddelerde zikredilen süreler geçmedikçe, kadın başka bir erkek ile evlenemez.

Madde 108- Yukarıdaki maddelerde belirtilen iddetin başlangıç tarihi, kadın bu olaylara muttali olmasa bile durumuna göre tefrik ve kocanın ölüm tarihidir.

Madde 109- Sahih akitle veya 70 . madde gereği fâsit ve bâtıl kabul edilen akitlerde fiilî birleşmeden önce talak gerçekleşir veya fesih ve tefrik ile hükmolunursa iddet gerekmez.

Madde 110- (Eşine) ric'at etmek üzere 96. madde gereği kendisine üç ay süre (mehil) verilen koca bu dönüşün gerçekleşmesinden (rücû'un vukûundan) önce vefat ederse, kadının vefattan dolayı iddet beklemesi gerekir. Hamileliğin asgari süresi 180, azami süresi ise 300 gündür.

Madde 111- Hamilelik sebebiyle iddetin azami sınırı, vefat veya boşamada, ölüm veya boşamanın meydana geldiği tarihten itibaren; tefrik durumunda ise bu kanunun 115 ve 119. maddelerinin hükmüne göre hâkim, tarafların ayrı meskende ikametlerini emretmiş ise bu emir tarihinden; eğer böyle bir emir yoksa tefrik hükmünün verildiği tarihten itibaren 300 gündür.

\section{BOŞANMAYA İLIŞKIN USÛL HÜKÜMLERI}

\section{I Müracaat Şekli}

Madde 112- Tefrik talebinde bulunan veya boşanmak isteyen koca veya karı, dilekçesini bizzat (şahsen-doğrudan) hâkime verir.

\footnotetext{
${ }^{i g}$ Bu maddenin bilahare tedvin edileceği ifade edilmektedir. Bkz. Cerîde-i Adliyye, Sayı 27 , s.20 (1036).

2) Kanun taslağının 80-106. maddeleri Ceride-i Adliyye'nin Teşrîn-i Evvel 1340 tarih ve 3. sene 27. sayısının 17.20(1033-1036) ıncı sayfalarında neşredilmiştir.
} 
Madde 113- Hâkimin huzuruna bizzat gidemeyecek derecede mazereti olduğu usûlüne uygun olarak kesinleşen dilekçe sahiplerinin ifade ve talepleri hâkim veya naibi tarafından ikâmetgahlarında tespit edilebilir.

\section{II}

\section{Tefrik Davalarına İlişkin Usûl Hükümleri}

Madde 114- Hâkim, tefrik sebeplerinden birisine dayanarak, tefrik talebinde bulunan davacıya talebini sözlü (şifâhî) olarak açıklatır. Kendisine, bu talebinin doğuracağı sonuçları anlatarak uygun bir şekilde nasihat eder.

Davacı (müddêे) bu nasihatleri dinlemeyerek tefrik kararı talebinde (istihsâlinde) ısrar ederse hâkim, belirlediği günde tarafların bulunmalarının zorunlu olduğunu, dilekçenin altına işaret eder.

Madde 115- Hâkim, diğer tarafın mahkemede bulunmasını (celbini) emretmekle beraber, tefrik talebinde bulunan koca ise, (eşlerin) ayrı yerde oturmasına izin verebilir, zevce ise ikâmetgahını bizzat kendisi belirleyebilir. Hâkimin bu kararları temyiz edilemez (kâbil-i temyîz de ğildir).

Madde 116- Tefrik dilekçesi çağrı kağıdı (celpnâme) ile birlikte mübaşir tarafından kapalı zarf içerisinde davalıya (müddeâ aleyh) tevdi edilir.

Madde 117- Çağrı kağıdının tebliğ ediliş tarihi ile hâkim huzuruna çıkma günü arasında davalıya sefer müddeti dışında en az üç gün süre (mehîl) verilir.

Madde 118- Hâkim, belirlenen günde bizzat tarafları dinler ve aralarını düzeltmeye çalışır.

Şayet taraflardan birinin, mazereti sebebiyle hâkimin huzuruna gelmesi mümkün olmazsa hâkim, ara bulma/uzlaştırma teşebbüsünün cereyan edeceği yeri (mahalli) tayin eder veya davahyı usûlüne uygun olarak görevlendirme (istinâbe) yoluyla dinler.

Madde 119- Tarafların uzlaşması mümkün olmadığı veya davalı özürsüz olarak (mahkemeye) gelmediği takdirde hâkim, durumu kayıt ve tespit ederek davaya doğrudan katılması (mübâsseret) ve iddiasını ispat etmesi için davacıya ruhsat (izin) verir ve tarafların ayıı konutta oturması ve kişisel eşyaların birbirlerine teslimi ve dava sonuçlanıncaya kadar çocukların korunma şekli ve nafaka hakkında hemen icra edilebilir, geçici karar verebilir. Bu kararlar, esas hakkında hüküm verilmeden (lâhik olmazdan) önce 15 gün zarfında temyiz edilebilir. Davacı, davaya katılmak için almıs olduğu ruhsat tarihinden itibaren 20 gün içinde hâkime müracaatla muhakeme gününü tayin ettirir. Aksi takdirde önceki fıkra hükmüne göre kendi lchine çıkan geçici kararlar hükümden düşer.

Madde 120-115. maddeye ve bir önceki maddenin II. fikrası hükmüne göre, (belirli) bir mahalde ikâmet etmesi istenen karı, dava sonuçlanıncaya 
kadar hâkimin izni olmaksızın ikâmetgahını değiştiremez. Aksi takdirde kocadan nafaka yükümlülüğü düşer; davacı karı ise, davasının düşmesine karar vermesini mahkemeden talep edebilir.

Madde 121- Tefrik davası, 84. maddeye dayanarak taraflardan birinin diğerine evlilik rabıtasının devamını imkânsız kılacak şekilde zulüm ve eza etmesi; veya 87. maddede açıklandığı gibi aralarında anlaşmazlık (nizâ') ve şikâk ortaya çıkması sebebiyle vâki olmuş ve hâkim tarafından karı-kocanın anlaşmaları (te'liff-i beyn) da sağlanamamış (kâbil olmamış) ise, davanın evvel emirde bu hakem hey'etine (hey'et-i hakemiyeye) tevdî edilmesi zorunludur.

Hakemler, uygun sayıda olmak üzere tarafların ailelerinden hâkim tarafından belirlenir. Taraflardan birinin veya her ikisinin ailesinden hakem tayin edilecek kimse bulunamamasi veya bulunanların da hakem olacak niteliklere sahip (hâiz) olmaması durumunda dışarıdan uygun olanlar tayin edilir.

Madde 122- Hakem hey'eti, tarafların ifade ve savunmalarını tetkik ederek (eşlerin) aralarını düzeltmeye (ıslâh) çalışır. Araları bu defa da düzeltilemediği ve hakem hey'eti, karı-koca arasında iyi ilişkilerin (hüsn-i mübâşeret) veya evlilik rabıtasının devamına imkân kalmadığına kanaat getirmesi durumunda aralarını tefrik etmekle birlikte, kusur, tamamen kocada ise 61. madde gereği belirlenen (tesmiye edilen) mehrin, 62. madde mûcebince de kararlaştırılan mâlî taahhütlerin ve iddet nafakasının tamamen ödenmesine hükmeder. Karı, hibe edilen malı kocasından; mevcut ise aynen, yok olmuş ise bedelini geri isteyebilir.

Eğer kusur tamamen karıda ise 61. madde gereği mehrin; 62. madde gereğince de kendi lehine ödenmesi şart koşulan para veya malın tamamını ve iddet nafakası (hakkı) nı, kaybeder ve koca hibe edilen malı karısından, mevcut ise aynen, yok olmuş ise bedelini geri alabilir.

Eğer hem koca hem de karı kusurlu bulunursa, mehir veya mâlî taahhütlerden bir kısmının ve iddet nafakasının ödenmesinc hükmeder.

Hakemler (kusurlu olan tarafın tespitinde) görüş birliğine varamazlarsa hâkim, gerekli nitelikleri hâiz başka bir hakem hey'eti veya taraflara yakınlığı (karâbet) olmayan diğger bir hakem tayin eder.

Hakemlerin vereceğ̣i hüküm, tescilden sonra, tebliğ edildiği tarihten itibaren 15 gün zarfında temyiz edebilir.

Madde 123- 84. ve 87. maddeler dışında kalan tefrik davaları, usûlüne uygun olarak ait olduğu mahkemelerde görülür ve sonuçlandırılır. Mahkeme, karı-kocanın tefrikine hükmederse, sadece kocanın veya sadece karının ya da her iki tarafın kusurlu olması durumlarını dikkate alarak mehri ve mâlî taahhütleri, hibe edilen malların geri istenmesini ve iddet nafakası iddialarmı bir önceki madde hükmüne uygun olarak takdir eder ve (davayl) sonuçlandırır. Şu kadar ki, bu davaların görülmesi sırasında iddianın 84 ve 87. maddelere ilişkin olduğu anlaşıldığ 1 takdirde davanın, mahkemece hakem hey'etine havalesi mecburîdir. 
Madde 124- Mahkeme veya hakem hey'etince tefrik kararı verildiği takdirde, akit sırasında mehir belirlenmemiş (tesmiye edilmemiş) veya taraflar arasında 62. maddeye uygun olarak (tevfikan) tefrik söz konusu olması durumunda verilmek üzere mâlî taahhütlerde bulunulmamış ise tamamen kusursuz olan tarafın diğer taraftan mahkeme marifetiyle tazminat talep etme hakkı vardır.

Madde 125- Tefrik davasının görüldüğü sırada davalı veya vekili tarafından usûlen bir dilekçe takdim edilerek, mukabil dava açılabilir (dava ikamesi).

Madde 126- Davaya bakan (vaz'l yed eden) mahkeme, 115 ve 119. maddeler gereği verilen geçici kararları, gerektiğinde (lede'l-hâce) tadil ve ikmal edebileceği gibi; mezkur maddelerde belirlenen hususlar hakkında, istenmesi halinde (lede't-talep) yeniden ve hemen icra edilebilen geçici kararlar verebilir.

(Hâkim) ayrıca, taraflardan veya aile fertlerinden birinin veya savcıların (müddêे-i umûmî) talebi üzerine veya re'sen çocukların menfaati için gerekli gördüğü hususlar hakkında geçici ve hemen icra edilebilen kararlar alabilir.

Madde 127- Çağrı belgesi (celpnâme), davalının gaipliği sebebiyle şahsına tebliğ edilememiş ise mahkeme, davanın esasına girmeden önce, gazeteler vasıtasıyla davalıyı, davadan haberdar eder ve mahkemeye çă̆ırır. Tefrik hakkındaki giyabî hükümler özel mübaşir marifetiyle tebliğ edilir.

Eğer hüküm, aleyhine hüküm verilen kişinin (mahkûm-u aleyh) şahsına tebliğ edilmemiş ise, hâkim belirleyeceği bir gazetede hükmün özetinin yayınlanmasını istek hâlinde (lede't-talep) emreder.

Gıyabî hüküm, aleyhine hüküm verilen kişinin (mahkûm-u aleyh) §̧ahsına tebliğ edilmiş ise, tebliğ tarihinden itibaren ve hukuk muhakemeleri usûlüne göre 15 gün; eğer tebliğ edilmemiş ise hüküm özeti fıkrasının gazetede neşredildiği tarihten itibaren üç ay içerisinde hükme itiraz edilebilir.

Madde 128- Tefrik talebinden sonra karı ve kocanın uzlaşması (i'tilâf) davayı düşürür. Bununla beraber davanın düşmesi yeni sebeplerin ortaya çımması durumunda yeni bir dava ikamesine engel olmaz. Bu takdirde davacı eski sebepleri de ileri sürebilir (dermeyân edebilir).

Madde 129- Tefrik davası, tarafların birinin muhakeme süresinde veya hüküm kesinlik kazanmadan önce vefat etmesi durumunda düşer.

Madde 130- Tefrik sebeplerinden işbu kanunun 77. maddesinde belirtilen akıl hastalı̆̆ (cinnet); 80 . maddesinde ifade edilen gaiplik (mefkûdiyet) ve 82 . maddesinde yer alan mahkûmiyet sebepleriyle açılan tefrik davalarında işbu faslın uzlaştırma teşebbüslerine ilişkin hükümleri geçerli olmaz. 


\section{III}

\section{Boşamaya İlişkin Usûl Hükümleri}

Madde 131- 94 ve 95. maddelerin hükümlerine göre boşama (talâk) hakkını kullanmak üzere huzuruna gelen koca veya karıya; hâkim tarafından hareketinden doğacak sonuçlar açıklanır ve uygun şekilde nasihat edilir.

Koca veya karı bu nasihatleri dinlemeyerek talâkın gereğini yaparsa (talebinde israr ederse), hâkim, işbu kanunun 96, 97, 98, 99 ve 100 . maddelerindeki hükümleri tatbik eder.

Madde 132- Boşamak/boşanmak ( $\hat{k} \hat{a}-\iota$ talâk) amaciyla hâkim huzuruna gelen koca veya karı, talebini tefrik davasına çevirebilir veya boşama sebebi olan anlaşmazlığın (nifâk ve şikâk), bir kere de 121. madde hükmüne göre teşkil olunacak hakem hey'eti huzurunda tetkik edilip bir karara bağlanmasını isteyebilir.

Madde 133- Sebep göstermeye ve duruşmaya teşebbüs etmeyerek 94. maddeyi gerekçe göstererek hâkim veya hakem hey'eti huzurunda karısını boşayan koca, 61. madde gereği, belirlenen mehri; veya talâk ve tefrik halinde 62 . madde gereği ödenmesi kararlaştırılan mal veya parayı ve iddet nafakasını tamamen ödeme yükümlülüğünü üstlenmiş olur ve karı hibe edilen malı kocasından mevcut ise aynen, yok olmuş ise bedelini geri isteyebilir.

Şayet akit sırasında mehir belirlenmemiş veya taraflar arasında 62 . maddeye göre taahhütlerde de bulunulmamış ise, bu şekilde boşandığından dolayı zarar gören taraf (mutazarrır) olacağı iddiasıyla karının tazminat talep etme hakkı vardır.

Madde 134- Gerckçe göstermeksizin ve duruşmaya gelmeksizin 95. maddeye dayanarak elde ettiği boşanma hakkını (tefevvud -i talâk) hâkim veya hakem hey'eti huzurunda kullanan kar1, 61. madde mûcebince belirlenen mehrini veya 62 . madde mûcebince koca tarafindan ödenmesi taahhüt edilen mal veya parayı kocasından talep edemez ve iddet nafakasını kaybeder. Koca hibe edilen malı karısından, mevcut ise aynen, yok edilmiş ise bedelini geri isteyebilir.

Şayet akit sırasında mehir zikredilmemiş veya taraflar arasında 62. madde hükmüne uygun olarak taahhütlerde de bulunulmamış ise tefvîz hakkının bu şekilde kullanılmasından zarar gören kocanın, karısından tazminat talep ve iddia etme hakkı vardır.

\section{IV}

\section{Feshe İlişkin Usûl Hükümleri}

Madde 135-37, 71, 72, 74 ve 76. madde hükümlerine göre veya kanûnen belirlenen fesat veya butlan sebeplerinden birine dayanarak 50 . 
madde gereği açılacak nikahın feshi davalarında bundan önceki I ve II. bölümlerde yer alan usûl hükümleri geçerli olmaz. Bunlar hakkında Hukuk Muhakemeleri Usûlü'nün genel hükümleri tatbik edilir.

\section{Boşanma (Müfârakât) İle İlgili Ortak Hükümler}

Madde 136- Mahkeme, aile hukukuna ilişkin herhangi bir davanın gizli olarak görüşülmesine karar verebilir.

Madde 137. Boşanma (müfârakât) davalarındaki muhakeme safhalarının, herhangi bir şekilde neşir ve ilan edilmesi yasaktır. Bu yasağa aykın hareket edenler 50 liradan 200 liraya kadar para cezasına mahkum edilirler.

Madde 138- Boşanma (ikâtı talâk) sicilinin veya fesih ve tefrik hakkındaki hakem kararının özeti, hükmü veren mahkemenin duruşma salonundaki (dîvânhâne) özel yere asılır, bir sûreti de resmî vilâyet gazetesiyle hususî gazetelerden birine dercedilir.

Madde 139- Talâk, fesih veya tefrik ile karının, kocanın soyadını taşıması yasaktır. Kadın, yeniden kendi aile ismini (soyadını) alır.

Madde 140- Boşanma kararı kesinlik kazandıktan sonra, nikahın ilk defa (ibtidâen) tescil edildiği yerde tescil edilir.

Talâkın tescili ile fesih ve tefrik hükmünün kesinlik kazanması durumunda koca ve karıya mahkemece özel bir belge (vesikka-i mahsûsa) verilmesi zorunludur.

-Geçici Madde-

27. maddeye göre evlilik akdinin (münâkehât) tescili ile görevli özel memur, nahiye merkezlerinde ikâme edilinceye kadar köylerde cereyan edecek nikah akitnâmesi o köyün bağlı bulunduğu (tâbi olduğu) nahiye merkezinde ve köy kanunun mûcebince hakem yetkisi (salâhiyet) verilen ihtiyar heyeti huzurunda düzenlenebilir ve nikahın nasıl tescil edildiği derhal hâkime bildirilir.

Şu kadar ki ilan süresi içinde itiraz. edilmiş ise bunun tetkiki hâkime aittir. Hâkim tarafında bir karar çıkmasına ve ilan süresinin geçmesine kadar nikah akdi yapılamaz. Aksi takdirde ihtiyar heyeti hakkında 60. madde hükümleri tatbik olunur.

Madde 141- İşbu kanun, yayın (neşir ve ilan) tarihinden itibaren tam 100 gün sonra geçerli (mer'iyyü'l-icra) dir.

Madde 142- İşbu kanunun hükümlerini yürütmeye (icra-i ahkâmına) Adalet ve İçişleri Bakanları memurdur. ${ }^{41 *}$

¿' Kanun taslağının 107-142. maddeleri. Cerìde-i Adliyye'nin Teşrîn-i Sânî, 1340) tarih ve 3. sene 28. sayısının (17-23) 1117-1123. sayfalarında neşredilmiştir.

- Kanun lâyihasını. 1917 tarihli Hukuk-1 aile Kararnamesi ve Bulgaristan Başmüftülüğünce hazıırlanan 1924 tarihli Münâkehât ve Mufârekât Talimatnamesi ile mukayese için Sabri 


\section{BIBLIYYOGRAFYA}

Ahkâm-ı Şahsiyye Komisyonu Zabıtları, Cerîde-i Adliyyc 12. sayıya ilave forma. Cerîde-i Adliyye, Sayı 33, s.953.

Albayrak, Sadık, Son Devir Osmanlı Ulemâsı, Zafer Matbaası, İstanbul 1981.

Berki, Ali Himmet. "Memlekctimiz Kıymetli Evlâdından Birini Daha Kaybetti", Diyanet Işleri Başkanlığı Dergisi, c.IV, sayı, 7-8. Temmuz- Ağustos 1965.

Ceride-i Adliyye, sene 1. Sayı 10, Mayıs 1339; Ağustos 1340, sene: 2, Sayı 25, s.888-891; Sayı 26. s.953-957; Sayt 27, s.1033-1036; Sayı 28, s.1117-1123.

el-Kâsânî. Alâuddîn chû Bckr b. Mesûd, Bedâiu's-Sanâi' fî Tertîbi'ş-Şerâi', Dâru'l-Küttâbi']Arabî, Bcyrut 1974.

Gönenli, Mehmet, “Mesele-i Me'mûniyye”, Ankara Barosu Dergisi. Sayı 6, 1953.

Gönenli, Mehmet. "Mesele-i Minberiyye ve Mesele-i Şüreyhiyye”, Ankara Barosu Dergisi, Sayı 6, 1953.

Gönenli Mehmet' in Adliye Vekaleti Umûr-i Zâtiye Müdüriyeti'ndeki 3393 no'lu dosyası.

İbnu'l-Hümâm, Kemalüddîn Muhammed b. Abdilvâhid. Fethu'l-Kadir Ale'l-Hidâye, Matbaatu Kübra'l-Emîriyye, Bulak 1316.

Köseoğlu, Cemalettin, "Büyük Bir Hukuk Bilgininin Ölümü” Adalet Dergisi. Yıl:56, Sayı 78, (Tcmmuz-Ağustos 1965).

Meşihat-ı Celîle-i İslâmiyye, Ilmiyye Sâlnâmesi (Meşihât-ı Celîle-i İlâmiyye'nin Cerîde-i Resmiyyesine Mûlhak), Matbaa-ı Âmire, İstanbul 1334.

Seçkin. Recai, Yargıtay Tarihçesi Kuruluş ve Işleyişi, Ankara 1967.

Şakir Ansay'ın Eski Aile Hukukumuza Bir Nazar, Ankara 1953 isimli eseri ile H.Mehmet Günay'ın "Bulgaristan Başmüfrülüğünce Hazırlanan 1924 Tarihli Münâkehât ve Mufârekât Talimatnamesi ve Bulgar Şer'iyye Mahkemelerinde Uygulanışı" isimli makalesine (Sakarya Universitesi Ilahivat Fakiultesi Dergisi. 2001/3. ss. 163-196) bakılabilir. 